DOI: https://doi.org/10.15276/hait.04.2021.2

UDC $004.942+621.923$

\title{
Optimization of the precision gear grinding operation based on integrated information system
}

\author{
Vasily P. Larshin ${ }^{1}$ \\ ORCID: https://orcid.org/0000-0001-7536-3859; vasilylarshin@gmail.com. Scopus Author ID: 7801669969 \\ Olga B. Babiychuk ${ }^{1)}$ \\ ORCID: https://orcid.org/0000-0002-0623-265X; obbabiychuk@ukr.net \\ Oleksandr V. Lysyi ${ }^{2)}$ \\ ORCID: https://orcid.org/0000-0002-7389-1161; lenafox107@gmail.com \\ Serhii M. Verpivskyi ${ }^{2}$ \\ ORCID: https://orcid.org/0000-0002-1610-4707; vsm1964@ukr.net \\ Zhang Yunxuan ${ }^{1)}$ \\ ORCID: https://orcid.org/0000-0001-9384-5042; zyx525770768@gmail.com \\ 1) Odessa National Polytechnic University, 1, Shevchenko Ave. Odessa, 65044, Ukraine \\ 2) Odessa Military Academy, 10, Fontanskaya Doroga Str. Odessa, 65009, Ukraine
}

\begin{abstract}
In accordance with the principles of hierarchical management, a comprehensive two-level management system is presented for the development and manufacturing of products for the stages of pre-production (the upper level of the management hierarchy) and for the actual production stage (the lower level of the management hierarchy). At the stage of pre-production, the gear grinding operation design on the "MAAG" type machines was carried out. For this purpose, a technique for optimizing the gear grinding parameters for a two dish-wheel rolling scheme has been developed, a mathematical optimization model containing an objective function with restrictions imposed on it has been created. The objective function is the gear grinding machine time, which depends on the operation parameters (gear grinding stock allowance, cutting modes, grinding wheel specification, part material) and the design features of the gears being ground (module, diameter, number of teeth, radius of curvature of the involutes). The article shows that at the stage of pre-production, the gear grinding optimization is a method of operation design. At the stage of actual production, a closedloop automatic control system with feedback on the deviation of the adjustable value (gear grinding power) automatically supports the numerical power values that were found at the operation design stage, taking into account ensuring defect-free high-performance gear grinding (minimum number of working strokes and maximum longitudinal feeds). At this stage, i.e. when a robust longitudinal feed automatic control system is operating, the optimization carried out at the previous stage (pre-production) sets the functioning algorithm for the adaptive system with corresponding control algorithm. Thus, at the production stage (when the gear grinding machine is running), the operation optimization is a control method. Therefore, it is shown that with two-level control, the gear grinding operation optimization performs a dual function. On the one hand, it is a design method (at the pre-production stage), and on the other - a management method (at the actual production stage). With this approach, i.e. with the integration of production and its preparation based on a single two-level management, the efficiency of a single integrated design and production automation system is significantly higher due to general (unified) optimization, rather than partial one.
\end{abstract}

Keywords: Information support; design and production; hierarchical control; rolling method; grinding defects; objective function; optimization model; operation design; control system

For citation: Larshin V. P., Babiychuk O. B., Lysyi O. V., Verpivskyi S. M., Yunxuan Zhang. Optimization of the precision gear grinding operation based on integrated information system. Herald of Advanced Information Technology. 2021; Vol. 4 No. 4: 303-317. DOI: https://doi.org/10.15276/hait.04.2021.2

\section{INTRODUCTION}

The Fourth Industrial Revolution (Industry 4.0) is the ongoing automation of traditional manufacturing and industrial practices, using modern smart technology. The modern interpretation of the term "automation" has two definitions. According to the first definition, automation is the replacement of manual labor with machine labor. According to the second definition, automation is the development of new technological processes and operations that cannot be implemented manually. The latter is most consistent with the Industry 4.0 trend. In addition,

(C) Larshin V., Babiychuk O., Lysyi O., Verpivskyi S., Yunxuan Zhang, 2021 the latter definition implies the use of automatic, adaptive and intelligent control systems at various levels of the management hierarchy within the framework of the concept of multilevel (hierarchical) management.

The article considers a two-level management system that corresponds to the traditional concept of product development and production. This concept includes the stages of pre-production and production itself. At the first stage (the upper level of the hierarchy), a model for optimizing the gear grinding operation was developed. At the second stage (the lower level of hierarchy), the optimal parameters of the gear grinding operation are automatically maintained by adjusting the longitudinal feed while stabilizing the gear grinding power.

This is an open access article under the CC BY license (http://creativecommons.org/licenses/by/3.0) 
In modern jet and turbojet aircraft engines, gear wheels (hereinafter gears) in power mechanical transmissions operate at circumferential speeds of up to $100 \mathrm{~m} / \mathrm{s}$ at extremely permissible contact and bending stresses in the gear teeth. In order to reduce dynamic loads and improve the smooth operation of the transmission, such gears must be manufactured with high accuracy. The gears high accuracy (up to the fourth degree) made of high-strength steels with a surface hardness of 60-62 HRC is known to be achieved by gear grinding.

Tooth grinding is one of the main methods of finishing hardened gears and is carried out either by the rolling method or by the copying one. It is known that a special feature of machines operating by the rolling method of tooth generation with two dish wheels (MAAG SD-32-X, HSS10S, HSS30BC, HSS30X machines, as well as domestic 5851, $5851 \mathrm{M}$ machines, etc.) is high processing accuracy up to fourth grade. For example, when grinding satellite gears of high-speed aircraft gearboxes, a degree of accuracy of 6-5-5X is typically obtained. The high accuracy of gear grinding here is due to the fact that the conical-concave cutting surface of the grinding dish wheels occupies a constant axial position during grinding. For this purpose, a special adjustment mechanism is used, which automatically compensates for the wear of the grinding wheels. However, the rolling method, unlike other methods of gear machining, is characterized by low productivity and, in addition, high thermal stress, which is aggravated by the lack of cooling (grinding is carried out without grinding fluid). The appearance of burns on the working surface of the teeth dramatically reduces the operational properties of the gears and in some cases (for example, in the aviation industry) grinding defects (burns and microcracks) are generally unacceptable. Therefore, improving the efficiency of defect-free gear grinding on MAAG machines is a very urgent task in mechanical engineering technology.

\section{LITERATUREREVIEW}

\subsection{General}

There are two toothed surface machining methods (Fig. 1). Each of them has its pros and cons [1].

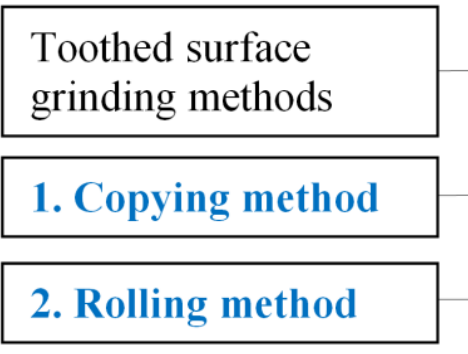

Fig. 1. Toothed surface grinding methods classification

Source: compiled by the authors
The method of copying is based on the fact that the shape of the gear cavity repeats the profile of the grinding wheel (Fig. 2), which is being machined. The method has the following pros.

1. Simplicity of obtaining a modification along the tooth profile and modification along the tooth line (barrel modification). The modifications eliminates edge contact of the teeth (especially highloaded gears), reduces noise in the transmission [2].

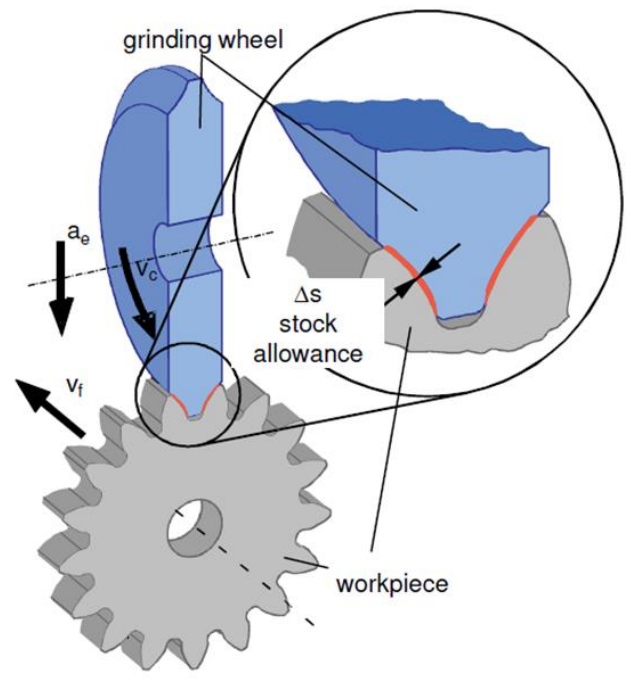

\section{Fig. 2. Copying method with a profile grinding wheel in gear grinding Source: compiled by [1]}

2. Higher productivity with fewer teeth.

3. The possibility of straightening (dressing) a grinding wheel for processing gears with different profile angles with a single diamond roller.

4. The possibility of dressing the grinding wheel in the machining cycle with the subsequent automatic compensation of the grinding stock allowance removed during the correction to obtain the wheel's precision parameters.

The method of rounding (or rolling method) is based on the reproduction of the gear workpiece engagement and the worm grinding wheel, which results in an involutes profile on the gear (Fig. 3).

\begin{tabular}{|l|}
\hline \multicolumn{2}{|c|}{ Rolling method } \\
\hline $\begin{array}{l}\text { 2.1. That with worm } \\
\text { grinding wheel }\end{array}$ \\
\hline $\begin{array}{l}\text { 2.2. That with two } \\
\text { dish grinding wheels } \\
\text { (MAAG method) }\end{array}$ \\
\hline
\end{tabular}

\section{Fig. 3. Rolling method classification} Source: compiled by the authors 
To implement this method, precise synchronization of the worm grinding wheel and the gear to be machined is necessary [2]. The method has the following pros.: a higher productivity when machining gears with a large number of teeth.

There are minuses, namely: (1) the complexity of adjustment for obtaining modifications, (2) the complexity of changing over when changing over to another type of product (setting the diamond rollers to a different tooth width, changing the rollers when grinding wheels have a different profile angle, etc.), (3) higher cost of worm grinding wheels.

Another method of rounding (rolling method) embodiment is that of MAAG gear grinding with two the so-called dish grinding wheels: 0-degree and 15-degree methods (Fig. 4).
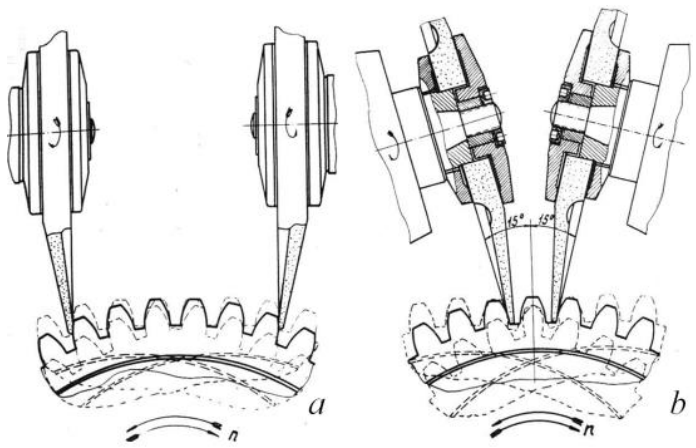

Fig. 4. Formation of an in volute profile during gear grinding at $0^{\circ}(a)$ and $15^{\circ}(b)$ installation of dish grinding wheels Source: compiled by the authors

This method is more accurate (the forth accuracy degree), but less productive compared to the gear grinding with a worm grinding wheel. A distinctive feature of MAAG method is the absence of forced cooling with a grinding fluid since the workpiece heating with this method is insignificant.

\subsection{Manufacturing preparation as the top level of the management hierarchy}

The pre-production stage is the most important in the system of preparation and launching the product for production. In this sense, this stage should be considered as the top level of the management hierarchy. At this level, fundamental decisions are made and tolerances (permissive limits of deviations) are set for the recommended parameters for the lowerlevel control system [3].

Some new principles for the design of intelligent systems are proposed including the statement that the control intelligence is hierarchically distributed according to the principle of increasing precision with decreasing intelligence (IPDI), evident in all hierarchical management systems [4]. This principle allows considering production management as a single process that covers the stages of production preparation (the upper level of the hierarchy) and production itself (the lower level of the hierarchy). However, in [4] nothing is said about the flow of information from the lower level to the upper one for correcting decisions made at the upper level [5].

\subsection{Control system operation at the hierarchy lower level}

It is obvious that every operation, as part of the process, should be automatically regulated at every moment of time. This means that the current technological transformations must be carried out on time and even just in time, i.e. with a minimum time delay. Such transformations are made on the lower level of hierarchical (multilevel) control system and must be prepared in advance the gear grinding operation [3].

Automatic regulation is a branch of the more general science of control - cybernetics. The control is understood as a set of actions that ensure the operation of a system based on the achievement of a predetermined goal without the participation of the operator. The robust automatic control system makes it possible to ensure the required quality of regulation even if the mathematical model of this system is somewhat incorrect. The modern understanding of the essence of automatic devices is based on the concept of an algorithm. The algorithm for an automatic device (both operation and control algorithms) is an information description of the processes of both operation and control (Fig. 5). The formal means for such a description are diverse: spoken language, graph (diagram), formulas, diagrams, etc.

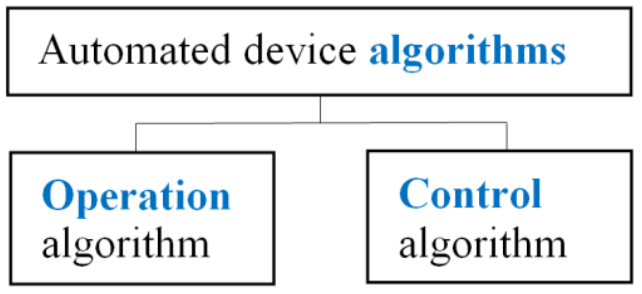

\section{Fig. 5. Two kinds of algorithms for automated device Source: compiled by [5]}

These features of modern technology require such cutting (grinding) process automation, which at high productivity will provide the required machining quality, taking into account both the actual machinability and anisotropy of the properties of these materials. Such requirements can be implemented only by high-speed control system at the lower hierarchical level [5]. At the present stage of production development, the higher level of the management hierarchy seems to be the technological preparation 
of production. This follows from the analysis of literary sources on optimization of systems and operations $[6,7]$. To apply the mathematical results and numerical techniques of optimization theory to concrete engineering problems, it is necessary to clearly delineate the boundaries of the engineering system to be optimized, to define the quantitative criterion on the basis of which candidates will be ranked to determine the "best", to select the system variables that will be used to characterize or identify candidates, and to define a model that will express the manner in which the variables are related. This composite activity constitutes the process of formulating the engineering optimization problem. Good problem formulation is the key to the success of an optimization study and is to a large degree an art $[7,8]$.

The executive mechanism of a robust automatic control system by deviation should perceive the fluctuation of the grinding power not as a random factor, but as a useful signal for an instant change in feed $V_{f}$, i.e., simultaneously with the deviation occurrence its compensation is carried out within the powers of the lower control level system (without involving the middle and upper control levels).

According to [9], there are two type of control systems, namely with open- and closed loop chain (Fig. 6).

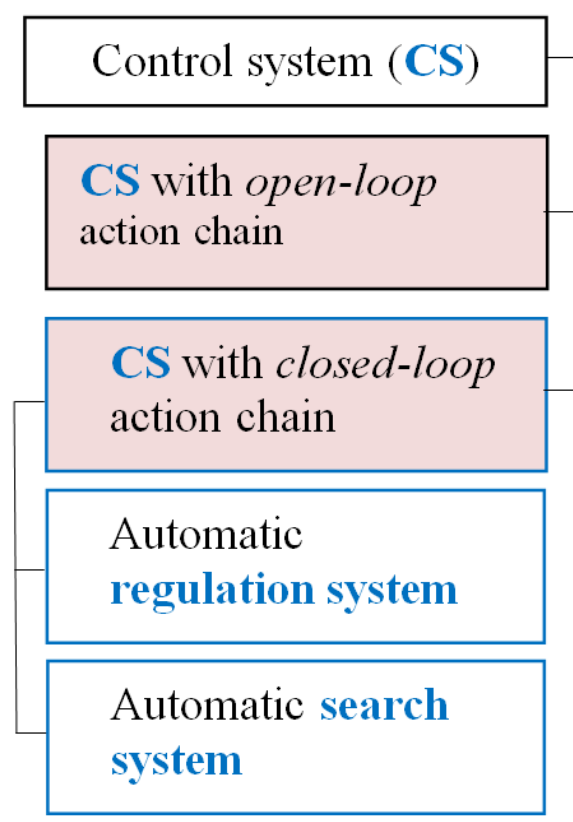

\section{Fig. 6. Classification by the nature of the control algorithm Source: compiled by [9]}

In turn, the latter may be with deviation or disturbance control (Fig. 7).

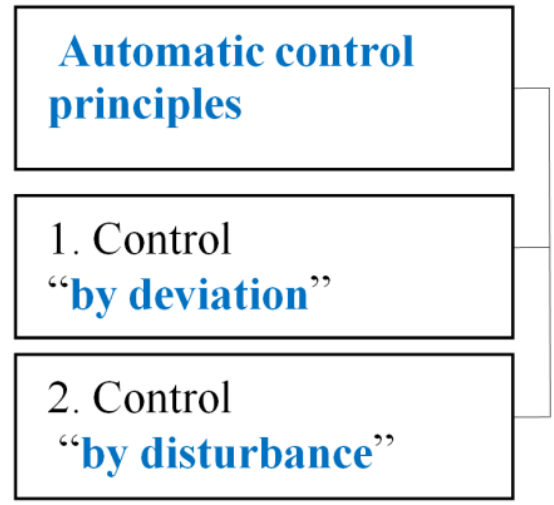

Fig. 7. Two main methods of automatic control Source: compiled by the authors

An example of the control system with deviation control is shown in Fig. 8, where a plant (control object) may be both the construction (a device having its components in space) and the process (a sequence of actions in time), e.g., gear grinding operation. Besides, there are three types of control systems by the nature of the operation algorithm (Fig. 9).

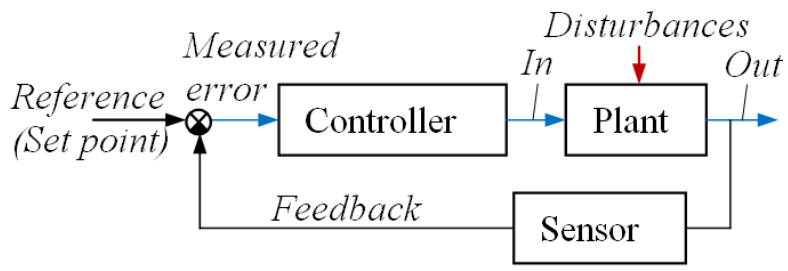

Fig. 8. Control system "by deviation" Source: compiled by the authors

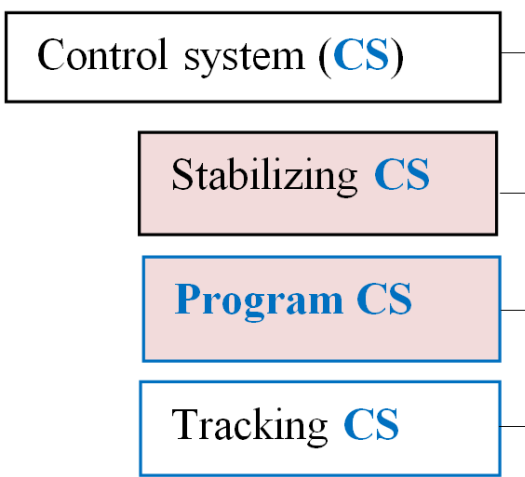

Fig. 9. Classification by the nature of the operation algorithm Source: compiled by [7]

The issues of developing a model for optimizing the gear grinding operation on machines of the MAAG type, as well as the application of these models at the pre-production stage have not yet found the required reflection in the literature.

The development of intelligent and adaptive systems has found application in the development of 
modern mechatronic technological systems, including ones in robotics and for creating high-tech products correcting the cutting mode parameters in $\mathrm{CNC}$ systems $[10,11]$.

An analysis of the grinding operations shows the importance of the temperature factor in ensuring the quality of the surface integrity of the gears being ground [11]. In this regard, there are studies on the genetic algorithm using [12, 13], biomedical technology [14, 15], engineering diagnosing [16, 17], numerical control elements as well as implants production using additive technologies [18].

The purpose of the article is to develop a hierarchical two-level control system and appropriate interaction between these levels, when the first (higher or upper) control level is that at the stage of pre-production (development and optimization of the operation, preparation of the control program), and the second (lower) level is a robust automatic deviation control system that stabilizes the optimal conditions for the operation. Besides, at the lower level of such a control the robust control system have to be used.

\section{RESEARCH METHODOLOGY}

\subsection{Consistent two-level management}

Two-level management at the stages of preproduction and production allows creating a single integrated design and production automation system. In such a system, optimization plays the part of both a design method (at the upper level of hierarchical management) and a control method - at the lower level.

Let us explain the above in greater detail

(Fig. 10). In the language of control system theory, on the upper control level a relative decision is making which is not based on some control (reference) points depending on the machine shop actual conditions. Consequently, it will be some formal decision. On the contrary, a robust control system on the lower control level takes into account the shop actual conditions. Sometimes, it will be with the help of the so-called RDT and E laboratory (an intermediary between the upper and lower levels of control).

\subsection{Optimization model creation}

In mechanical engineering technology, the labor intensity of an operation is usually characterized by the estimated time per piece $T_{p p}$, which contains the following time components: machining time $T_{m}$ (main component), auxiliary time $T_{a}$, workplace maintenance time $T_{w p}$, personal needs time $T_{p n}$, and preparatory-final time $T_{p f}$, i.e.

$$
T_{p p}=T_{m}+T_{a}+T_{w p}+T_{p n}+T_{p f} / n
$$

where $n$ is the batch size (the number of pieces in the batch).

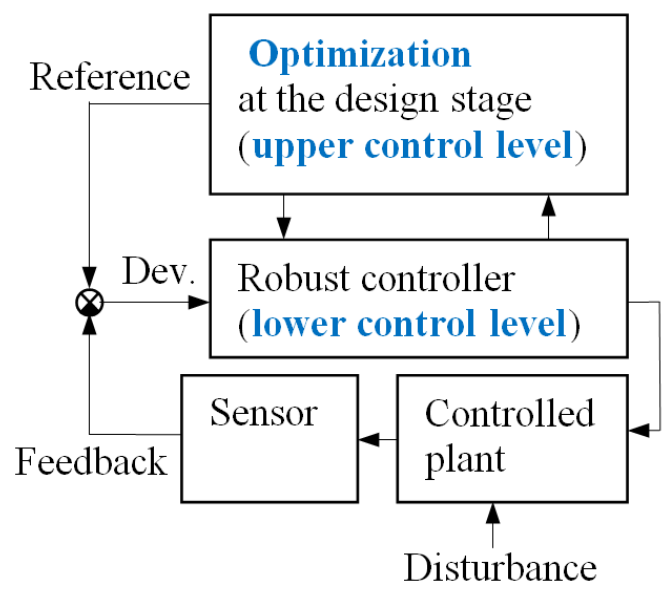

\section{Fig. 10. General scheme of two levels hierarchical automatic control system Source: compiled by the authors}

The efficiency of the machine operator is estimated by the calculated coefficient of machining time $K_{m t}$ that can be found as follows

$$
K_{m t}=\frac{T_{m}}{T_{p p}}=\frac{T_{m}}{T_{m}+T_{a}+T_{w p}+T_{p n}+T_{p f} / n} .
$$

The higher this coefficient, the more efficiently the work is organized and the higher its return. This coefficient for universal machines with manual control is 0.4-0.5, for CNC machines - 0.8, and for machining centers -0.95 . Gear grinding machines of the MAAG type do not have a CNC system; they belong to the class of machines with cyclic control. That is why, for these machine type $0.4<K_{m t}<0.5$. This situation accounts for the search for opportunities to reduce the machining time $T_{m}$ in gear grinding.

To create a model for optimizing the stock removal cycle during gear grinding, experimental studies of the factors influencing the labor intensity of this operation were carried out. From the experimental data obtained, it follows that an increase in the grinding power leads to a corresponding increase in the temperature in the grinding zone. It is known that an increase in temperature leads to an increase in the depth of the grinding burn [10]. This will be reflected in the equations below based on corresponding scientific researches.

Therefore, additional experimental studies were performed to establish the relationship between the depth of burn and the power of gear grinding (Fig. 11). 


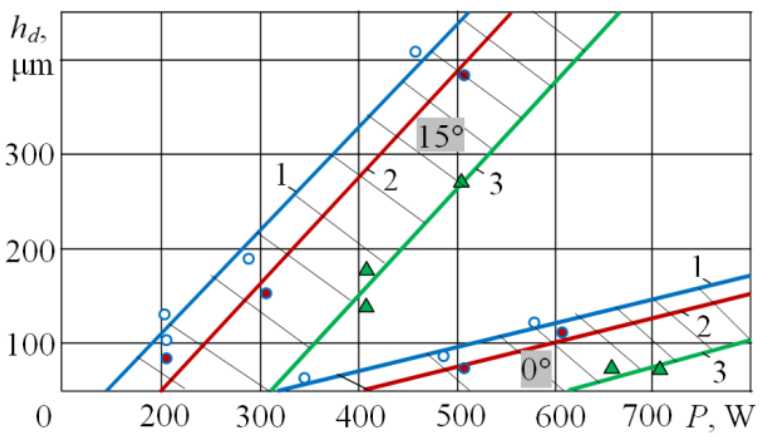

Fig. 11. Influence of gear grinding power $P$ on the defective layer depth $h_{d}$

$(1,2$, and 3 - see in text)

Source: compiled by the authors

The experimental data processing allowed obtaining the following dependence for the gear grinding power $P$ :

$$
P=c t^{x} V_{f}^{y} n_{0}^{z} k_{\mathrm{m}} k_{w} k_{\rho},
$$

where: $c, x, y, z$ are the coefficients depending on the angle of dish grinding wheels installation $\left(0^{\circ}\right.$, $\left.15^{\circ}\right) ; t, V_{f}$ and $n_{0}$ are the depth of cut (mm), longitudinal feed $(\mathrm{mm} / \mathrm{min})$, and gear swings frequency (roll rate in $\min ^{-1}$ ); $k_{\mathrm{m}}, k_{w}$ and $k_{\rho}$ are the coefficients that take into account the influence of the material to be grinding, abrasive wheel, and tooth profile curvature radius, respectively.

From formula (1), we determine the time spent on the $k$-th working stroke $(1 \leq k \leq n)$, i.e.

$$
\tau_{k}=\frac{L}{V}=\frac{L\left(c t_{k}^{x} n_{0}^{z} k_{m} k_{t} k_{\rho}\right)^{1 / y}}{P_{k}^{1 / y}} .
$$

Let us introduce the following designations:

$$
\alpha=\frac{x}{y} ; \varepsilon=\frac{1}{y} ; M=L\left(c n_{o}^{z} k_{m} k_{t} k_{\rho}\right)^{1 / y} .
$$

Hence, we have

$$
\tau_{\kappa}=M \frac{t_{k}^{\alpha}}{P_{k}^{\varepsilon}} .
$$

The total machine grinding time spent on $n$ working strokes will be

$$
\tau_{n}=M \sum_{k=1}^{n} \frac{t_{k}^{\alpha}}{P_{k}^{\varepsilon}} .
$$

One of the main factors limiting the gear grinding productivity is the grinding burn depth $h_{d}$. For any $k$-th working stroke, the defect layer depth $h_{d k}$ formed during gear grinding can be represented by the following dependence

$$
h_{d k}=a\left(P_{k}-P_{0}\right)^{\gamma},
$$

where: $a$ and $\gamma$ are coefficients; $P_{0}$ is the gear grinding power defect less level in $\mathrm{W}$.

Numerical values of coefficients $a$ and $\gamma$ can be established from the experimental data (Fig. 11) on which it is indicated the following: $15^{\circ}$ and $0^{\circ}$ are the grinding dish wheels installation angles; 1,2 and 3 are the materials to be ground, namely $12 \mathrm{X} 2 \mathrm{H} 4 \mathrm{~A}$, 18XHВA, and 12X2HВФA, respectively.

As follows from the experimental data (Fig. 11), the coefficient $\gamma$ can be taken equal to 1, i.e. $\gamma=1$. Hence, the last expression can be written as follows

$$
h_{d k}=a\left(P_{k}-P_{0}\right) \text {. }
$$

Since for any $k$-th $(1 \leq k \leq n)$ working stroke the depth of the defective layer formed during gear grinding should not exceed the gear grinding stock allowance remaining for grinding, then

$$
h_{d k}=\sum_{i=k+1}^{n} t_{i}=Z-\sum_{i=1}^{k} t_{i} .
$$

Taking into account equations (6) and (7) we get

$$
P_{k}=\left[\left(Z-\sum_{i=1}^{k} t_{i}\right) / a\right]+P_{0} .
$$

After substituting this expression into equation (4), we get a general mathematical expression for the machine time of gear grinding when removing the grinding stock allowance for $n$ working strokes.

The grinding depth for the last $n$-th working stroke is found by the equation:

$$
t_{n}=Z-\sum_{i=1}^{n-1} t_{i}
$$

Therefore, corresponding equation that resulting from equation (6) has the following form: 


\subsection{Random search algorithm}

Optimal grinding depths can be found by sequentially differentiating equation (12) $(n-1)$ times by the following variables: $t_{1}, t_{2}, \ldots, t_{n-1}$. Further, each of the $(n-1)$ equations (for the derivatives) is equated to zero and we obtain a system of $(n-1)$ equations with $(n-1)$ unknowns. However, the procedure for solving the system of transcendental equations obtained in this way is complex. Therefore, a direct method of finding the minimum values of the objective function (12), namely the random search method [19], was used. The method includes the following procedure.

1. Set some initial values to variables (cutting depths) $t_{1}, t_{2}, \ldots, t_{n-1}$ from a predetermined range of their possible change.

2. Calculate the value of the objective function (12) at this point and remember this random value (the point $\tau_{n}\left(t_{1}, t_{2}, \ldots, t_{n-1}\right)=X_{0}$ in Fig. 12).

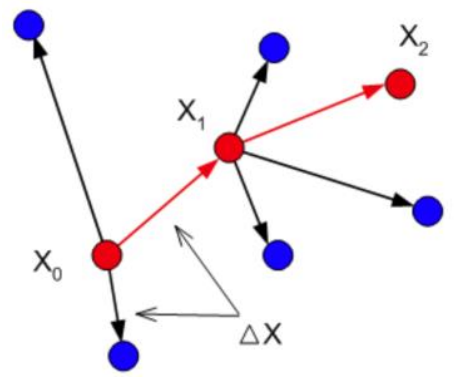

The points at which the improvement of the objective function was achieved

The points at which the value of the objective function has not improved

Fig. 12. A simple non-adaptive algorithm for random search of a local optimum Source: compiled by [19]

3. Set random increments to fixed values of variables $t_{1}, t_{2}, \ldots, t_{n-1}$ and the next value of the objective function (12) $\tau_{n}\left(t_{1}, t_{2}, \ldots, t_{n-1}\right)$ is calculated again, which differs from the previous value $X_{0}$ by increment $\Delta X$, i.e. $X_{0}+\Delta X$. Fig. 12 shows three random directions from the point $X_{0}$ : up, right and down. If the new calculated value $\tau_{n}\left(t_{1}, t_{2}, \ldots, t_{n-1}\right)=X_{1}$ is less than the previous one (in Fig. 12, a transition from point $X_{0}$ to point $X_{1}$ is selected from three possible transitions, namely to the right), then the point $X_{1}$ becomes the new current point (Fig. 12). The transition from point $X_{1}$ to point $X_{2}$ is performed in the same way, etc.
4. RESULTS

\subsection{Gear grinding operation design}

To understand the essence of the objective function (12) let consider the case $n=2$. For this case equation (12) takes the following form

$$
\tau_{2}\left(t_{1}\right)=M\left[\frac{\left(Z-t_{1}\right)^{\alpha}}{P_{0}^{\varepsilon}}+\frac{t_{1}^{\alpha}}{\left[\left(Z-t_{1}\right) / a+P_{0}\right]^{\varepsilon}}\right]
$$

For this case, i.e. for $n=2$, optimal gear grinding stock allowance distribution is graphically shown in Fig. 13.

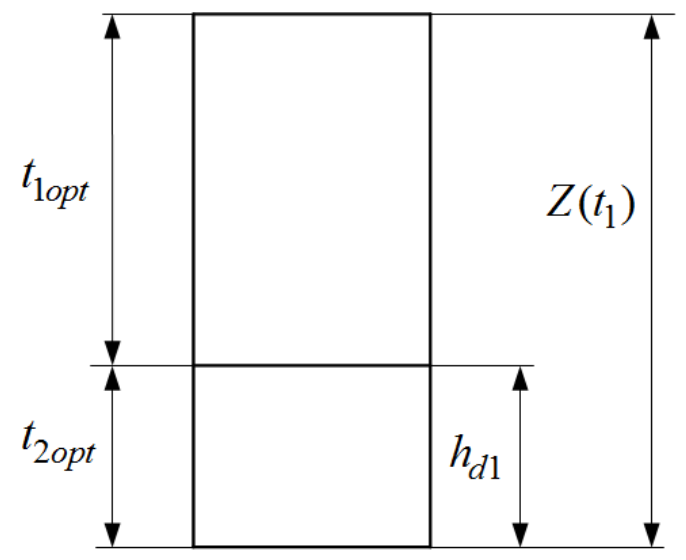

\section{Fig. 13. Optimal stock allowance distribution for $n=2$ Source: compiled by the authors}

For the $0^{\circ}$ angle of the dish wheels installation and for the $n_{0}=150 \mathrm{~min}^{-1}$ the following parameters values in equations mentioned above are received: $\alpha=0.79 ; \varepsilon=1.05 ; P_{0}=126 \mathrm{~W}$, and $M=3.04$.

The graphical dependences constructed according to equation (13) at $Z=400 \mu \mathrm{m}, Z=350 \mu \mathrm{m}$, and $Z=325 \mu \mathrm{m}$ are shown in Fig. 14. Each of these dependencies is constructed by changing the value $t_{1}$ in the range of $20 \leq t_{1} \leq 375$, provided that $Z=t_{1}+t_{2}$.

From the data shown in Fig. 14, it can be seen that all three dependencies have a unimodal (smooth and convex) shape and an unambiguously expressed global extremum - minimum of the function $\tau_{2}\left(t_{1}\right)$. For example, for grinding stock allowances $Z=400$ $\mu \mathrm{m}, Z=350 \mu \mathrm{m}$, and $Z=325 \mu \mathrm{m}$ the minimum grinding time $\tau_{2 \min }\left(t_{1}\right)$ and optimal grinding depths on the first $t_{1 \text { opt }}$ and second $t_{2 \text { opt }}$ strokes are given in Table 1. 


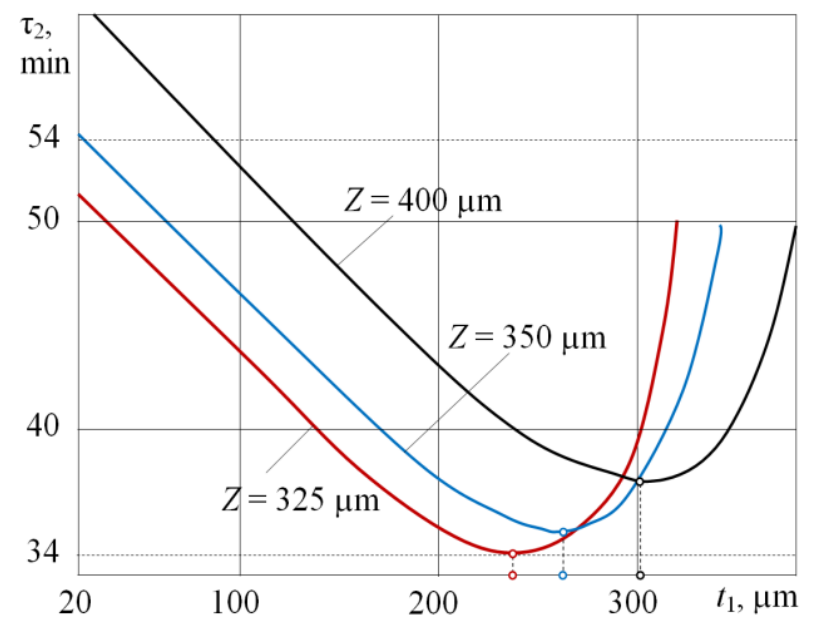

Fig. 14. The dependence of the machine time of gear grinding $\tau_{2}\left(t_{1}\right)$ on the cutting

depth on the first stroke $t_{1}$ for $n=2$ Source: compiled by the authors
Table 1. Optimal grinding parameters for $n=2$

\begin{tabular}{|l|l|l|l|l|l|}
\hline$Z, \mu \mathrm{m}$ & 400 & 350 & 325 & 200 & 100 \\
\hline$\tau_{2 \min }\left(t_{1}\right), \min$ & 37.7 & 35.5 & 34.4 & 26.9 & 18.6 \\
\hline$t_{1 \text { opt }}, \mu \mathrm{m}$ & 300 & 260 & 240 & 140 & 60 \\
\hline$t_{2 \text { opt }}, \mu \mathrm{m}$ & 100 & 90 & 85 & 60 & 40 \\
\hline $\begin{array}{l}\text { Note: the data for } Z=200 \mu \mathrm{m} \text { and } Z=100 \mu \mathrm{m} \\
\text { are not given in Fig. } 14 .\end{array}$ \\
\hline \multicolumn{7}{|l}{ Source: }
\end{tabular}

To find the extremum of the function, equation (13) can be represented as

$$
\frac{\tau_{2}\left(t_{1}\right)}{M}=\frac{\left(Z-t_{1}\right)^{\alpha}}{P_{0}^{\varepsilon}}+\frac{t_{1}^{\alpha}}{\left[\frac{Z-t_{1}}{a}+P_{0}\right]^{\varepsilon}} .
$$

By analogy with equation (14) and based on equation (12), it is possible to obtain equations for the machine time of gear grinding with a different number $n$ of gear grinding strokes. For example, such equations are presented below for $n=3$ and $n=4$.

$$
\begin{gathered}
\frac{\tau_{3}\left(t_{1}, t_{2}\right)}{M}=\frac{\left(Z-t_{1}-t_{2}\right)^{\alpha}}{P_{0}^{\varepsilon}}+\frac{t_{2}^{\alpha}}{\left[\frac{Z-t_{1}-t_{2}}{a}+P_{0}\right]^{\varepsilon}}+\frac{t_{1}^{\alpha}}{\left[\frac{Z-t_{1}}{a}+P_{0}\right]^{\varepsilon}} . \\
\frac{\tau_{4}\left(t_{1}, t_{2}, t_{3}\right)}{M}=\frac{\left(Z-t_{1}-t_{2}-t_{3}\right)^{\alpha}}{P_{0}^{\varepsilon}}+\frac{t_{3}^{\alpha}}{\left[\frac{Z-t_{1}-t_{2}-t_{3}}{a}+P_{0}\right]^{\varepsilon}}+\frac{t_{2}^{\alpha}}{\left[\frac{Z-t_{1}-t_{2}}{a}+P_{0}\right]^{\varepsilon}}+\frac{t_{1}^{\alpha}}{\left[\frac{Z-t_{1}}{a}+P_{0}\right]^{\varepsilon}}
\end{gathered}
$$

Objective functions in the form of recursive equations (14), (15) and (16) can be minimized without passing to derivatives of these functions and without composing a system of corresponding $(n-1)$ equations. A computer program, for example, a program for random search of optimal values, performs simultaneous random changing these values in a given range of their possible change. In this case, the instantaneous value of the objective function (12) and the trend of the sequence of these counts are estimated. The current set of optimization parameters which leads to a reduction in the machine time of gear grinding is fixed. Trends associated with an increase in the value of the objective function do not receive further development. As a result of numerous computational iterations and estimates of the trends obtained in this case, the computational process of searching for several values of variables (grinding depths for different strokes to be made) tends to asymptotically approach the minimum value of the objective function. This minimum value is fixing during the calculation and corresponding numerical values of variables (grinding depths) are output as a search result. As another example, data were obtained for $n=3$ (Table 2).

Table 2. Optimal grinding parameters for $n=3$

\begin{tabular}{|l|l|l|l|l|}
\hline$Z, \mu \mathrm{m}$ & 400 & 350 & 325 & 200 \\
\hline$\tau_{2 \min }\left(t_{1}\right), \min$ & 33.4 & 31.7 & 30.8 & 25.0 \\
\hline$t_{1 \mathrm{opt}}, \mu \mathrm{m}$ & 238.3 & 203.4 & 186.3 & 104.0 \\
\hline$t_{2 \mathrm{opt}}, \mu \mathrm{m}$ & 109.3 & 97.8 & 91.9 & 60.4 \\
\hline$t_{3 \mathrm{opt}}, \mu \mathrm{m}$ & 52.4 & 48.8 & 46.8 & 35.6 \\
\hline
\end{tabular}

Source: compiled by the authors

The practice of designing optimal gear grinding strokes has shown that as the number of variables in 
the objective function increases, the random search method is more reliable compared to the procedure for solving a system of $(n-1)$ equations with $(n-1)$ unknowns.

\subsection{Gear grinding automatic control}

Grinding on the MAAG type machines is characterized by a long grinding cycle during which the grinding parameters of this operation change significantly (due to cutting properties of the grinding wheel, instantaneous cutting depth changes, etc.).

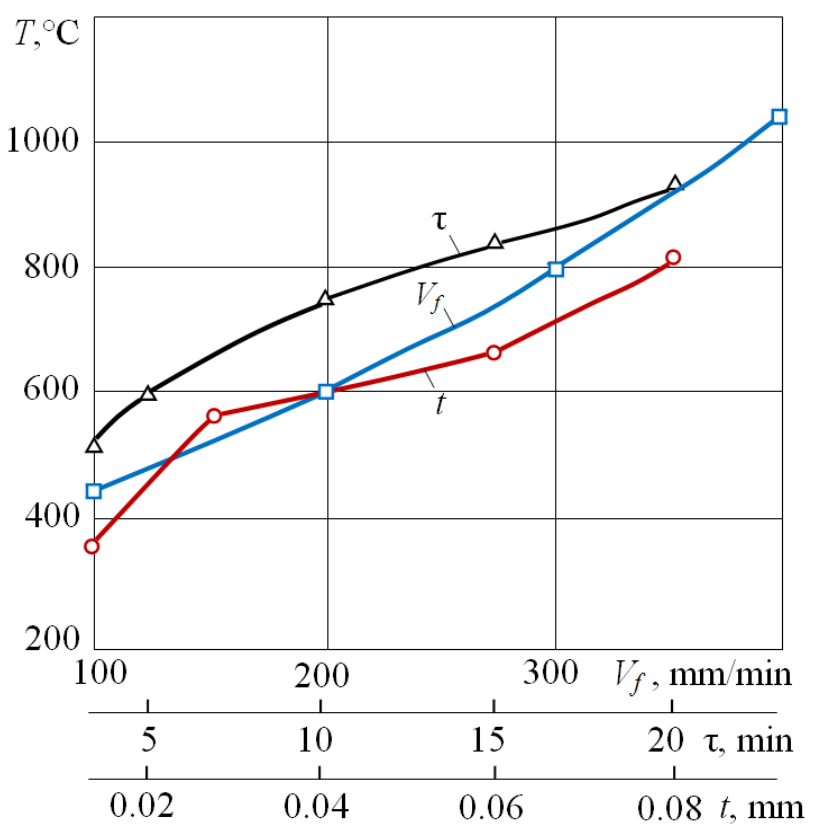

Fig. 15. The dependence of the grinding zone temperature $T$ on the grinding duration $\tau$, the longitudinal feed $V_{f}$ and the cutting depth $t$

Source: compiled by the authors

Stabilization of the grinding temperature in such conditions can be carried out using a robust automatic control system with feedback on the power spent on cutting. However, this parameter is not universal, since it indirectly characterizes the grinding temperature in the cutting zone. An experimental relationship between temperature and gear grinding power has been established (Fig. 15), which implies the possibility of limiting the temperature by limiting the level of gear grinding power. In other words, software control of the amount of gear grinding power $P\left(V_{f}\right)$ as the grinding stock allowance is removed and stabilization of gear grinding power by adjusting the longitudinal feed can be used to automate the grinding operation, as well as to implement an optimal cycle of the grinding stock allowance removal based on the relationship between the power $P\left(V_{f}\right)$ and the defective layer depth $h_{d}$ according to equation (7).

In this case, production management (at the gear grinding stage) is carried out according to a two-level control scheme: (1) optimization of the gear grinding operation at the pre-production stage (upper control level) and robust automatic control of the gear grinding power at the production stage (lower control level). At the same time, the optimization of the gear grinding operation is the method of designing this operation (at the stage of preproduction) and the method of controlling this operation (at the stage of actual production).

In addition, the information connection of the lower level of management with the upper level allows adjusting the initial parameters in the operation optimization model. This makes it possible to improve (on the basis of optimization) the functioning algorithm of the integrated CAD/CAM/CAE system. Fig. 15 shows that with an increase in the longitudinal feed $V_{f}$ from 100 to $400 \mathrm{~mm} / \mathrm{min}$, cutting depth $t$ from 0.01 to $0.1 \mathrm{~mm} / \mathrm{min}$, and grinding machine time $\tau$ from 2.5 to $20 \mathrm{~min}$, the grinding temperature in the contact zone increases from 440 to $1050^{\circ} \mathrm{C}$, from 350 to $850^{\circ} \mathrm{C}$, and from 510 to $960^{\circ} \mathrm{C}$, respectively.

The structural scheme of the developed digital system of automatic control of the power spent on gear grinding shows the main elements of this system (Fig. 16). The set values of the gear grinding power (system input "Setpoint") were calculated earlier at the pre-production stage. The developed structural scheme corresponds to the features of the gear grinding method on machines of the MAAG type. For example, two active electric power sensors operate simultaneously when two (left and right) electric motors drive two dish grinding wheels. From two simultaneously generated power signals (after subtracting idle power signals from them), a signal corresponding to the larger of the two power values is selected to control the longitudinal feed.

The low inertia of the drives of two dish grinding wheels creates prerequisites for the necessary speed of a robust system of automatic control of gear grinding power by changing the longitudinal feed of the table of the MAAG type gear grinding machine (e.g., MAAG HSS30X type). 


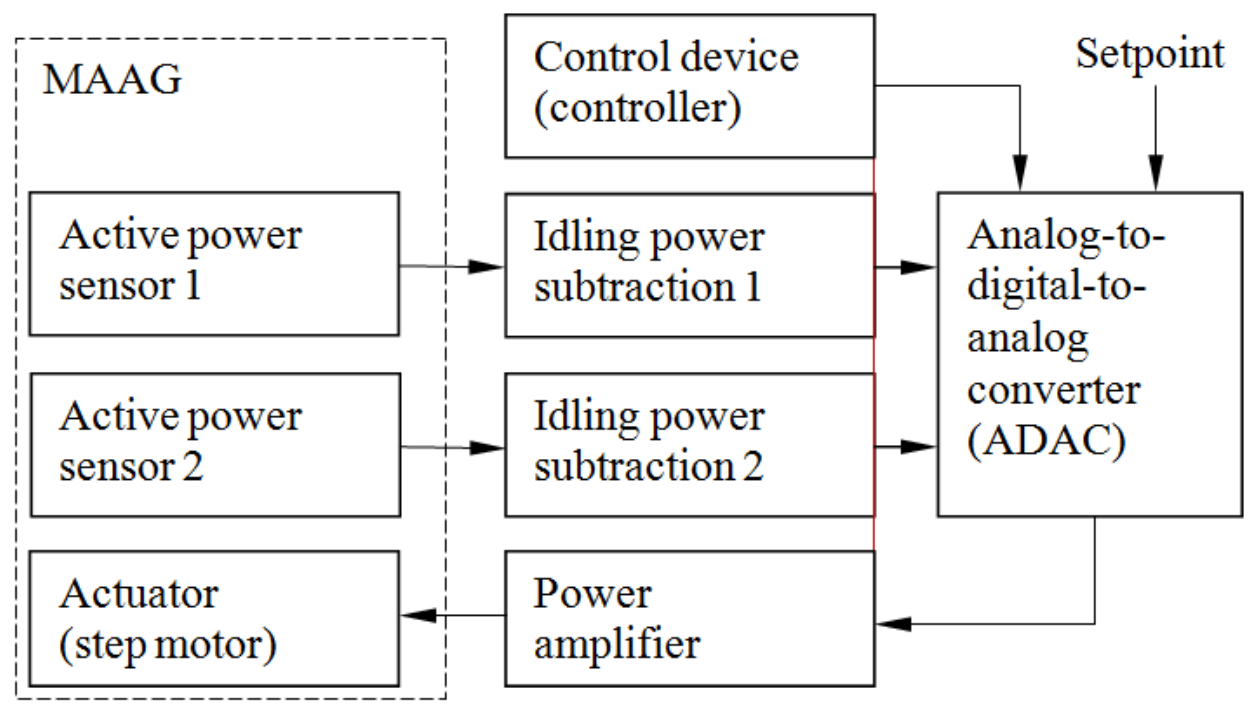

Fig. 16. Structural scheme of the automatic control system for MAAG gear grinding machine Source: compiled by the authors

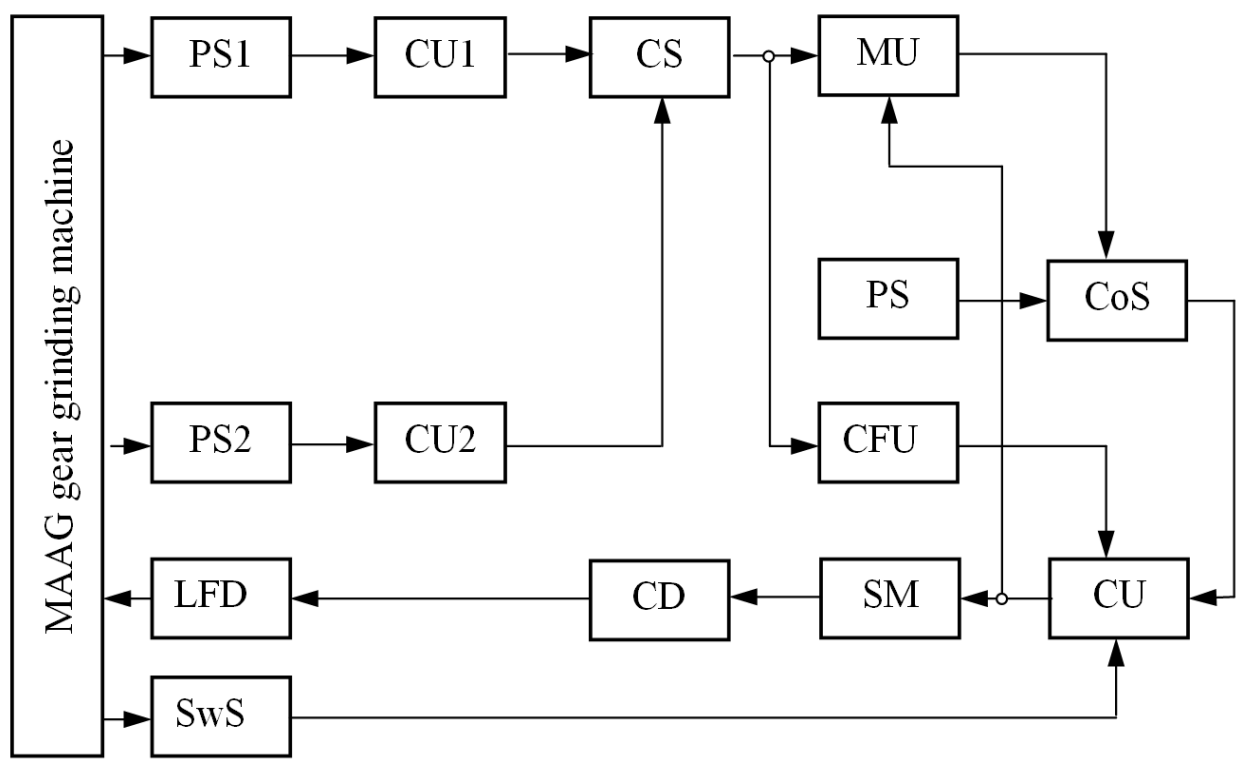

Fig. 17. Functional scheme of the automatic control system for MAAG gear grinding machine Source: compiled by the authors

In electronics and control theory, transfer functions are commonly used to design and analyze a system assembled from different in nature components, particularly using the block diagram technique (Fig. 17). The block diagram of the adaptive system contains the following components: active power sensors PS1 and PS2 of the electric motors of the dish grinding wheels' electrodrives and their corresponding blocks CU1 and CU2 for compensation of the idling power level, a scheme for selecting the most loaded electric motor of the grinding wheel drive CS, a memory block MU, a task block PS, a comparison scheme $\mathrm{CoS}$, a block for fixing cutting CFU (fixes the beginning and end of each working stroke), a control unit CU, a stepper motor SM, a correction device $\mathrm{CU}$, a swing sensor $\mathrm{SwS}$, and a longitudinal feed drive LFD. The power sensors PS1 and PS2 operate independently of each other. However, as an information signal at any given time, a signal is used only from the sensor that measures the power of the most loaded electric motor (i.e., one of the two mentioned). The choice of such a sensor is carried out by the selection scheme SC of the most loaded engine, the basis of which is the logic element OR. The memory block MU, containing a reversible pulse counter, a control circuit and a digitalto-analog converter, allocates and records peak values of the gear grinding pulse power.

The control unit CU generates control actions based on a signal from the swing sensor $\mathrm{SwS}$ and 
switches the windings of the stepper motor SM. It contains a rectangular pulse generator, a control circuit and a pulse distributor. The swing sensor SwS is a non-contact sensor of industrial manufacture (BVK type). The change in the longitudinal feed is carried out from the G68-11 type hydraulic piston valve.

The correction device CD compensates for the change in the transmission coefficient of the system when the grinding depth changes in accordance with the pre-calculated gear grinding stock allowance distribution (see Table 1 and Table 2).

The transfer function of the regulated object in a steady (static) mode can be represented as a transfer factor, i.e.

$$
k_{t f}=\frac{P\left(V_{f}\right)}{V_{f}},
$$

where: $P\left(V_{f}\right)$ is the gear grinding power (regulated value), $\mathrm{W} ; V_{f}$ is the longitudinal feed (regulating value), $\mathrm{mm} / \mathrm{min}$.

In turn, the gear grinding power depends on the grinding parameters, the characteristics of the abrasive grinding wheel, and the workpiece material machinability according to the equation (1).

Hence,

$$
k_{t f}=c t^{x} V_{f}^{y-1} n_{0}^{z} k_{m} k_{w} k_{\rho} .
$$

During gear grinding, the value of the transfer factor $k_{t f}$ changes by several times. In these conditions, to ensure the required regulation quality, an additional corrective device is introduced into the closed loop of the system, which changes $k_{t f}$ in such a way that

$$
k_{p r}=k_{c d} k_{t f}=\text { constant, }
$$

where: $k_{p r}$ is the coefficient which is proportional to the open system total transmission coefficient; $k_{c d}=\Delta V_{f} / \Delta x_{i n}$ is the corrective device transfer factor; $\Delta V_{f}$ and $\Delta x_{i n}$ are the increments of the input and output parameters at the point of the characteristic, which corresponds to the instantaneous value of the current $V_{f}$.

Taking into account equation (18) we get the following solution of the differential equation

$$
V_{f}=c_{d e} \exp \left(\frac{k_{c d}}{P} x_{i n}\right),
$$

where $c_{d e}$ is the integration constant.
For a MAAG type gear grinding machine, the nonlinear characteristic of the correction device described by the mathematical expression (19) is shown in Fig. 18.

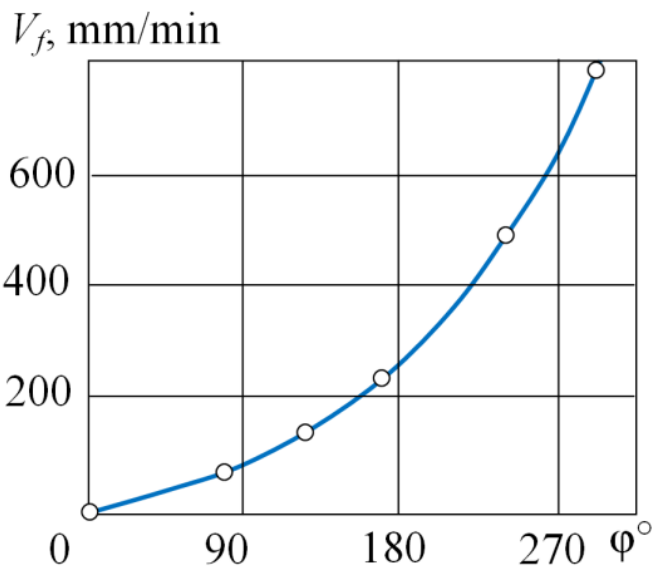

\section{Fig. 18. Calculated nonlinear characteristic of the correction device for MAAG HSS30X type grinding machine \\ Source: compiled by the authors}

The dependence in Fig. 18 can be realized by the profile of the cam mounted on the shaft of the stepper motor (SM in Fig. 17).

When gear grinding on the MAAG type machines, the workpiece receives fast rolling movements and a slow longitudinal feed. The last one can be adjusted from the condition of stabilizing the gear grinding power on the most loaded grinding wheel (of the two wheels working simultaneously). After moving the gear workpiece by a fixed amount of the longitudinal stroke of the machine table, the workpiece performs a dividing angular movement for $1 / z$ part of the full its revolution (here $z$ is the number of gear teeth). At the first contact of the grinding wheel with the next tooth side surface, a system operating state signal appears at the output of the cutting fixation unit (CFU in Fig. 17). At the command of the control unit $\mathrm{CU}$, the longitudinal feed $V_{f}$ of the machine table decreases to the minimum level $V_{f}=150 \mathrm{~mm} / \mathrm{min}$, and then gradually increases to the set-point level, the value of which depends on the power value set in the PS unit (Fig. 17). The control actions in the control system are performed at discrete points in time with the frequency of pulses that come from the swing sensor $\mathrm{SwS}$; the deviation of the actual cutting power from the set one is determined with the same frequency.

The efficiency of MAAG HSS30X type grinding machine equipped with the automatic control system described was evaluated by the duration of gear grinding the gear while ensuring the required 
degree of the gear accuracy and the quality of its surface layer. On machine equipped with an adaptive system, the times for grinding gears with module $m=4, z_{1}=20, z_{2}=30$ and $z_{3}=60$ (the number of teeth), respectively, were 90, 110 and 220 minutes. When grinding the same gears on the same MAAG machines, but without the control system, the grinding times were 100, 200 and 500 minutes, respectively. The time for the gear grinding operation without the control system increases due to the fact that local increases in the grinding stock allowance on individual teeth (caused by the deformation of the gear) require a reduction in the grinding parameters when grinding all the teeth of the gear (and not only when grinding individual teeth having the deformation).

The following data were obtained on the accuracy of gear grinding without and with the control system. On one of the two gears, the accumulated step error $F_{P r}$ on the first gear before its grinding was $128 \mu \mathrm{m}$ on the right and $154 \mu \mathrm{m}$ on the left profiles, and on the other, respectively, $78 \mu \mathrm{m}$ and 124 $\mu \mathrm{m}$. When gear grinding with the control system after the first working stroke (in the mode $t=0.07$ $\mathrm{mm}$, the feed $V_{f}$ is adjustable, the gear dividing is two-sided, $n_{0}=180 \mathrm{~min}^{-1}$ ), the error $F_{P r}$ decreased from $128 \mu \mathrm{m}$ to $28 \mu \mathrm{m}$ on the tooth right involute profile and from $154 \mu \mathrm{m}$ to $20 \mu \mathrm{m}$ on the tooth left involute profile. After the second and third strokes, the error $F_{P r}$ decreased, respectively, to $16 \mu \mathrm{m}$ and 4 $\mu \mathrm{m}$ on the left and to $12 \mu \mathrm{m}$ and $3 \mu \mathrm{m}$ on the right profile of the teeth. When gear grinding without the control system, it took at least 6 strokes to reduce the error from $78 \mu \mathrm{m}$ to $3-4 \mu \mathrm{m}$ on the right profile and from $124 \mu \mathrm{m}$ to $3-4 \mu \mathrm{m}$ on the left profile.

\section{CONCLUSIONS}

1. The hierarchical control principle with the correct distribution of powers between different levels of the control makes it possible to increase the efficiency of the system of development and production by developing integrated design and production systems that are similar to the integrated
$\mathrm{CAD} / \mathrm{CAM} / \mathrm{CAE}$ system, since in such an integrated system, this efficiency is due to general, rather than part optimization.

2. The practice of designing optimal gear grinding strokes has shown that as the number of variables in the objective function increases, the random search method is more reliable compared to the procedure for solving a system of $(n-1)$ equations with $(n-1)$ unknowns. In turn, to obtain such a system of equations, it is necessary to perform $(n-1)$ differentiations of the objective function.

3. A closed-loop automatic control system of the second order (in terms of cutting power, regulating the longitudinal feed) is stable over a wide range of changes in the transfer function of the controlled plant (object). This is due to the short kinematic chain and low inertia of the electric motor of the grinding wheel drive. To expand the stability zone of the robust control system, a correction device with a transfer function (found in the article) should be introduced into the system closed circuit.

4. The closed robust system of automatic regulation of gear grinding power turns out to be effective, since the idling power level in this system does not exceed $30 \%$ of the power level spent on gear grinding (i.e., the ratio of the useful gear grinding power to the total active power of the electric motor is about $70 \%$ ).

5. Optimization of gear grinding parameters according to the criterion of the gear grinding minimum machine time is carried out on the basis of a systematic approach, according to which the theoretical calculation at the stage of pre-production (the upper level of the control hierarchy) is accompanied by automatic control of the gear grinding power at the production stage (the lower level of the control hierarchy).

\section{ACKNOWLEDGEMENTS}

This work was carried out in accordance with the state (Ukraine) budget theme of the Odessa National Polytechnic University (2018 - 2021, registration code: 0118U004400).

\section{REFERENCES}

1. Klocke, F. "Manufacturing Processes 2: Grinding, Honing, Lapping”. Publ. Springer Berlin: Germany. 2009. 433 p. - Available from: https://ua1lib.org/book/593653/d0309a?dsource=recommend. - [Accessed: March 2021].

2. "The main differences are the method of copying and the method of rounding". - Available from: http://www.vizas.org/en/methods-of-manufacturing.html. - [Accessed: March 2021]. 
3. Mitrishkin, Y. \& Haber, R. "Hierarchical control system for complex dynamical plants". Conference: ICINCO 2009. Proceedings of the 6th International Conference on Informatics in Control. Automation and Robotics, Intelligent Control Systems and Optimization. Milan: Italy. July 2-5, 2009.

4. Lima, P. U. \& Saridis, G.N. "Design of intelligent control systems based on hierarchical stochastic automata". World Scientific Publishing Co. Pte. Ltd. Singapore: 1996.

5. Larshin, V. P., Lishchenko, N. V., Babiychuk, O. B. \& Pitel', J. "Computer-aided design and production information support”. Herald of Advanced Information Technology. Publ. Nauka i Tekhnika. Odessa: Ukraine. 2021; Vol. 4 No. 2: 111-122. DOI: https://doi.org/10.15276/hait.02.2021.1.

6. Singiresu, S. R. "Engineering optimization: theory and practice". Third Edition. John Wiley \& Sons, Inc. New York: USA. 1996. 922 p. - Available from: https://b-ok.global/book/892988/b246c7. - [Accessed March 2021].

7. Ravindran, A., Ragsdell, K. M. \& Reklaitis, G.V. "Engineering Optimization: Methods and Applications", Second Edition. John Wiley \& Sons, Inc. Hoboken, New Jersey: USA. 2006. 667 p. - Available from: https://industri.fatek.unpatti.ac.id/wp-content/uploads/2019/03/019-Engineering-Optimization-Methods-andApplications-A.-Ravindan-K.-M.-Ragsdell-G.-V.-Reklaitis-Edisi-2-2006.pdf. - [Accessed: March 2021].

8. Reklaitis, G.V., Ravindran, A. \& Ragsdell, K. M. "Engineering Optimization: Methods and Applications", Wiley: New York. 1983.

9. Larshin, V. P. \& Gushchin, A. M. "Mechatronic technological system information support". Applied Aspects of Information Technology. Publ. Nauka i Tekhnika. Odessa: Ukraine. 2021; Vol. 4 No. 2: 153-167. DOI: https://doi.org/10.15276/aait.02.2021.

10. Lishchenko, N. \& Larshin, V. "Gear-Grinding Temperature Modeling and Simulation". Lecture Notes in Mechanical Engineering. Publ. Springer. 2020. p. 289-297. DOI: https://doi.org/ 10.1007/978-3030-22063-1_32, https://www.scopus.com/authid/detail.uri?authorId=7801669969.

11. Larshin, V., Lishchenko, N., Lysyi, O. \& Uminsky, S. "Intelligent numerical control of profile grinding". Ivanov, V. et al. (Eds.): DSMIE 2021, Lecture Notes in Mechanical Engineering. Publ. Springer. 2021. p. 203-212. DOI: https://doi.org/10.1007/978-3-030-77719-7_21, https://www.scopus.com/authid/ detail.uri?authorId=7801669969.

12. Komarov, O. "Reducing the search area of genetic algorithm using neural network autoencoder". Herald of Advanced Information Technology. Publ. Nauka i Tekhnika. Odessa: Ukraine. 2020; 3(3): 113124. DOI: https://doi.org/10.15276/hait.03.2020.1.

13. Dydyk, A., Nosovets, O. \& Babenko, V. "Setting up the genetic algorithm for the individualized treatment strategy searching". Herald of Advanced Information Technology. Publ. Nauka i Tekhnika. Odessa: Ukraine. 2020; 3(3): 125-135. DOI: https://doi.org/10.15276/hait.03.2020.2.

14. Shcherbakova, G, Krylov, V. \& Plachinda O. "Determination of characteristic points of electrocardiograms using multi-start optimization with a wavelet transform". Herald of Advanced Information Technology. Publ. Nauka $i$ Tekhnika. Odessa: Ukraine. 2020; 3(2): $23-33$. DOI: https://doi.org/10.15276/hait.02.2020.2.

15. Khoma, Y, Szmajda, M. \& Pelc, M. "Development of scientific-methodological approaches of machine learning application in biosignals processing". Herald of Advanced Information Technology. Publ. Nauka i Tekhnika. Odessa: Ukraine. 2020; 3(1): 383-394. DOI: https://doi.org/10.15276/hait.01.2020.5.

16. Shibaev, D., Vychuzhanin, V., Rudnichenko, N., Shibaeva, N. \& Otradskaya, T. "Data control in the diagnostics and forecasting the state of complex technical systems". Herald of Advanced Information Technology. Publ. Nauka $i$ Tekhnika. Odessa: Ukraine. 2019; 2(3): 183-196. DOI: https://doi.org/10.15276/hait.03.2019.2.

17. Romanyuk, O., Vyatkin, S., Antoshchuk, S., Mykhaylov, P. \& Chekhmestruk, R. "Blending functionally defined surfaces". Applied Aspects of Information Technology. Publ. Nauka i Tekhnika. Odessa: Ukraine. 2019; 2(4): 271-282. DOI: https://doi.org/10.15276/aait.04.2019.2.

18. Pasichnyk, V., Kryvenko, M., Burburska, S. \& Haluzynskyi, O. "Design and engineering assurance for the customized implants production using additive technology". In: Ivanov, V., Trojanowska, J., Pavlenko, I., Zajac, J., Peraković, D. (eds).“Advances in design, simulation and manufacturing IV”. DSMIE 2021. 
Lecture Notes in Mechanical Engineering. Springer. Cham. 2021. - Available from: https://www.google.com.ua/search?tbm=bks\&hl=ru\&q=https\%3A\%2F\%2Fdoi.org\%2F+10.1007\%2F978-3030-77719-7_9. - [Accessed: March 2021].

19. "Random search algorithm - Structuralist" - Available from: http://www.structuralist.narod.ru/ dictionary/rnd.htm. - [Accessed: March 2021].

Conflicts of Interest: the authors declare no conflict of interest

$\begin{array}{ll}\text { Received } & 28.02 .2021 \\ \text { Received after revision } & 02.03 .2021 \\ \text { Accepted } & 15.03 .2021\end{array}$

DOI: https://doi.org/10.15276/hait.04.2021.2

УДК $004.942+621.923$

\title{
Оптимізація операції прецизійного зубошліфування на основі інтегрованої інформаційної системи
}

\author{
Василь Петрович Ларшин ${ }^{1)}$ \\ ORCID: https://orcid.org/0000-0001-7536-3859; vasilylarshin@gmail.com. Scopus Author ID: 7801669969 \\ Ольга Борисівна Бабійчук ${ }^{1)}$ \\ ORCID: https://orcid.org/0000-0002-0623-265X; obbabiychuk@ukr.net \\ Олександр Васильович Лисий ${ }^{2}$ \\ ORCID: https://orcid.org/0000-0002-7389-1161; lenafox107@ gmail.com \\ Сергій Миколайович Верпівський ${ }^{2}$ \\ ORCID: https://orcid.org/0000-0002-1610-6860; vsm1964@ukr.net \\ Чжан Юньсюань ${ }^{1)}$ \\ ORCID: https://orcid.org/0000-0001-9384-5042; zyx525770768@gmail.com \\ 1) Одеський національний політехнічний університет, пр. Шевченка, 1. Одеса, 65044,Україна \\ 2) Військова академія, Фонтанська дорога, 10. Одеса, 65009, Україна
}

\begin{abstract}
АНОТАЦІЯ
Відповідно до принципів ієрархічного управління представлена комплексна дворівнева система керування розробкою і постановкою продукції на виробництво для етапів технологічної підготовки виробництва (верхній рівень ієрархії керування) і етапу власне виробництва (нижній рівень ієрархії керування). На етапі підготовки виробництва виконано технологічне проектування операції зубошліфування на верстатах типу MAAG. Для цього розроблена методика оптимізації параметрів зубошліфування для схеми обкату двома тарілчастими кругами, створена математична модель оптимізації, що містить цільову функцію з накладеними на неї обмеженнями. Цільовою функцією є машинний час зубошліфування, якій залежить від параметрів операції (припуск на обробку, режими різання, інструмент, матеріал деталі) і конструктивних особливостей оброблюваних зубчастих коліс (модуль, діаметр, число зубів, радіус кривизни евольвенти). Показано, що на етапі підготовки виробництва оптимізація операції є методом технологічного проектування. На етапі власне виробництва замкнута робастна система автоматичного керування зі зворотним зв'язком по відхиленню регульованої величини (потужності зубошліфування) автоматично підтримує чисельні значення потужності, які були знайдені на етапі проектування операції з урахуванням забезпечення бездефектного високопродуктивного зубошліфування (мінімальне число проходів і максимальні поздовжні подачі столу зубошліфувального верстата). На даному етапі, тобто при роботі робастної системи автоматичного керування поздовжньою подачею, оптимізація, яка проведена на попередньому етапі (підготовки виробництва), задає алгоритм функціонування адаптивної системи, який зумовлює відповідний алгоритм керування. Таким чином на етапі виробництва (при роботі верстата) оптимізація операції є методом керування. Тобто показано, що при дворівневому керуванні оптимізація операції зубошліфування виконує двоїсту функцію. 3 одного боку це метод проектування (на етапі підготовки виробництва), а 3 іншого - метод керування (на етапі власне виробництва). При такому підході, тобто при інтеграції виробництва і його підготовки на
\end{abstract}


основі єдиного дворівневого керування, ефективність єдиної інтегрованої системи автоматизації проектування і виробництва виявляється значно вище за рахунок загальної (тобто єдиної), а не часткової оптимізації.

Ключові слова: Інформаційне забезпечення; проектування та виробництво; ієрархічне керування; спосіб обкатки; дефекти шліфування; функція цілі; оптимізаційна модель; проектування операції; система керування
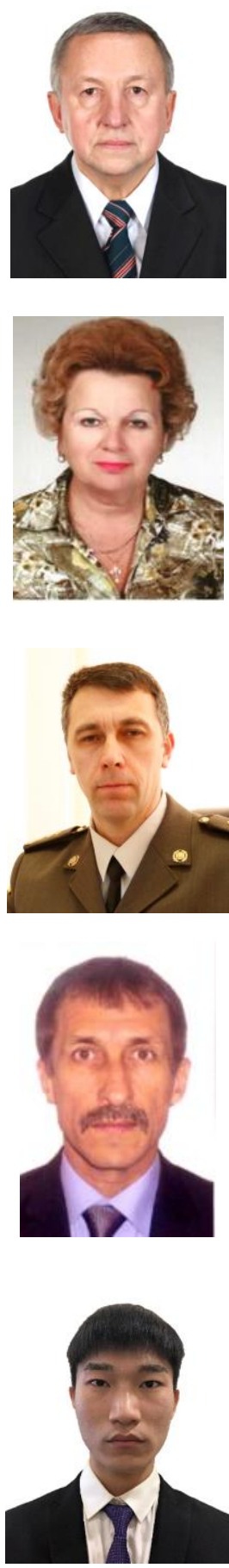

\section{ABOUT THE AUTHORS}

Vasily P. Larshin - Academician of the Ukrainian Academy of Economic Cybernetics, Dr. Sci. (Eng), Professor of Mechanical Engineering Technology Department. Odessa National Polytechnic University, 1, Shevchenko Ave. Odessa, 65044, Ukraine

ORCID: https://orcid.org/ 0000-0001-7536-3859; vasilylarshin@ gmail.com. Scopus ID: 7801669969

Research field: Production and technological processes information ensuring

Василь Петрович Ларшин - академік Української академії економічної кібернетики, доктор техніч. наук (1995), професор кафедри Технології машинобудування. Одеський національний політехнічний університет, пр. Шевченка, 1. Одеса, 65044,Україна

Olga B. Babiychuk - Senior Lecturer of the Institute of Computer Systems. Odessa National Polytechnic University, 1 , Shevchenko Ave. Odessa, 65044, Ukraine

ORCID: https://orcid.org/ 0000-0002-0623-265X; obbabiychuk@ukr.net

Research field: Computer simulation of electromechanical systems

Ольга Борисівна Бабійчук - старший викладач Інституту комп'ютерних систем. Одеський національний політехнічний університет, пр. Шевченка, 1. Одеса, 65044,Україна

Oleksandr V. Lysyi - Candidate of Engineering Sciences, Associate Professor of the Department of Military Vehicle Equipment, Head of the Department of Military Vehicle Equipment. Odessa Military Academy, 10, Fontnskaya Doroga Str. Odessa, 65009, Ukraine

ORCID: https://orcid.org/0000-0002-7389-1161; lenafox107@gmail.com

Research field: Information ensuring of the vehicle diagnosing systems

Олександр Васильович Лисий - кандидат технічних наук, доцент кафедри Автомобільної техніки, начальник кафедри Автомобільної техніки. Військова академія, Фонтанська дорога, 10. Одеса, 65009, Україна

Serhii M. Verpivskyi - Deputy Head of the Department of Military Vehicle Equipment. Odessa Military Academy, 10 , Fontnskaya Doroga Str. Odessa, 65009, Ukraine

ORCID: https://orcid.org/0000-0002-1610-4707; vsm1964@ukr.net

Research field: Information support of vehicle repair technology

Верпівський Сергій Миколайович - заступник начальника кафедри Автомобільної техніки. Військова академія, Фонтанська дорога, 10. Одеса, 65009, Україна

Zhang Yunxuan - Master of Mechanical Engineering Technology Department. Odessa National Polytechnic University, 1, Shevchenko Ave. Odessa, 65044, Ukraine

ORCID: https://orcid.org/0000-0001-9384-5042; zyx525770768@gmail.com

Research field: Technological processes information ensuring

Чжан Юньсюань - магістр кафедри Технології машинобудування. Одеський національний політехнічний університет, пр. Шевченка, 1. Одеса, 65044,Україна 